\title{
Topoisomerase I
}

National Cancer Institute

\section{Source}

National Cancer Institute. Topoisomerase I. NCI Thesaurus. Code C16516.

DNA topoisomerase I (765 aa, $291 \mathrm{kDa}$ ) is encoded by the human TOP1 gene. This protein plays a role in the regulation of DNA topology. 